Mr Živojin Petrović, kapetan I klase, dipl. inž. mr Radosav Nikolić, pukovnik, dipl. inž. mr Dragan Trifković, kapetan I klase, dipl. inž. Vojna akademija - Odsek logistike, Beograd

\section{OPREMA I METODOLOGIJA ENDOSKOPSKE DIJAGNOSTIKE}

UDC: $62-7: 681.518 .5$

Rezime:

Osnovni problem u održavanju tehničkih sistema sastoji se u proveri njihove radne sposobnosti $i$ otkrivanju neispravnosti u slučaju otkaza. Stanje tehničkih sistema najlakše se $i$ najbrže može utvrditi primenom savremenih metoda tehničke dijagnostike. Endoskopskom dijagnostikom moguće je utvrditi trenutno stanje tehničkih sistema. Zbog toga je neophodno poznavanje endoskopske opreme i definisanje metodologije primene endoskopske dijagnostike u održavanju tehničkih sistema.

Ključne reči: održavanje, endoskopska dijagnostika, oprema, metodologija.

\title{
EQUIPMENT AND METHODOLOGY OF ENDOSCOPY DIAGNOSTIC
}

\section{Summary:}

The basic problem in the maintenance of technical systems lies in the confirmation of their working capabilities and discovering malfunctions in case of breakdown. The condition of technical systems can be estimated in the fastest and easiest way by application of contemporary methods of technical diagnostic. The temporary state of technical systems can be estimated by endoscopy diagnostic. That is why it is necessary to get to know endoscopy equipment and define methodology application of endoscopy diagnostic in the maintenance of technical systems.

Key words: maintenance, endoscopy diagnostic, equipment, method.

\section{Uvod}

Endoskopska dijagnostika jedna je od mnogobrojnih metoda tehničke dijagnostike koja se primenjuje za posmatranje nepristupačnih mesta tehničkih sistema, bez njihovog rastavljanja [1].

Upotrebom odgovarajuće endoskopske opreme moguće je u zatvorenom, neosvetljenom i skučenom prostoru, pouzdano otkrivanje: prskotina, zareza, deformacija, korozije, erozije, istrošenja, izgoretina, gubitka zaštitnih prevlaka, naslaga, curenja i dr. Endoskop- ska dijagnostika se naročito koristi za posmatranje delova sistema u mračnim prostorima ili prostorijama gde je smanjena vidljivost [2].

Osnovni zadatak ove metode jeste da utvrdi trenutno stanje tehničkog sistema, na osnovu čega se donose odluke o postupcima i aktivnostima iz oblasti održavanja. Ovakvim pristupom praktično se prelazi sa održavanja prema rokovima rada na održavanje prema stanju. Prednosti održavanja prema stanju, pre svega, ogledaju se u povećanju pouzdanosti i efektivnosti tehničkih sistema, 
smanjenju troškova održavanja, a samim tim i troškova životnog ciklusa tehničkih sistema [3].

Neophodni uslovi za uspešnu primenu metode endoskopske dijagnostike su: oprema, metodologija i specijalizovan kadar. Endoskopsku dijagnostiku treba da sprovode posebno školovani i obučeni specijalisti, koji moraju da poseduju multidisciplinarna znanja. Osim poznavanja opreme i metodologije, oni moraju da se upoznaju i sa tehničkim karakteristikama sistema koji se dijagnosticiraju.

\section{Oprema za endoskopsku dijagnostiku}

Osnovu za vizuelnu i optičku kontrolu predstavlja ljudski vid i osvetljenje. U većini slučajeva postupci tehničke dijagnostike i kontrole moraju se izvršiti u uslovima lošeg osvetljenja ili, u najboljem slučaju, pri dnevnom svetlu. Upravo takvi uslovi ne pogoduju vršenju ozbiljne vizuelne kontrole, jer je osnovni nedostatak ljudskog oka da mu pri slabom osvetljenju ne pomažu čak ni najbolji optički instrumenti. Pri rukovanju endoskopskom opremom mora se voditi računa o mogućnostima i osobinama ljudskog vida, kako bi njena iskorišćenost bila što veća.

Drugi osnovni faktor koji uslovljava rad sa optičkom opremom je osvetljenje. Maksimalnu efektivnost osvetljenja obezbeđuje vlaknasti svetlovod sa kontinualnim vlaknima, $i$ to ukoliko se gubici bilo kog činioca vlakna svedu na 50\% intenziteta. Drugi način poboljšanja intenziteta osvetljenosti moguć je izborom prirode i snage svetlosnih izvora.
Usled ograničenih sposobnosti ljudskog oka klasične metode dijagnosticiranja u tehnici poseduju mnoge nedostatke. To je uslovilo razradu novih metoda $\mathrm{i}$ opreme kojima se sprovode vizuelna i optička posmatranja u oblasti tehničke dijagnostike. U tehnici se sve više koriste optička vlakna za posmatranje teško dostupnih sklopova i delova u raznim zatvorenim prostorima i otvorima, onda kada druge metode tehničke dijagnostike zahtevaju rastavljanje.

Prvi endoskopi (zajednički termin za sve uređaje za posmatranje sklopova i delova u zatvorenom prostoru) bili su projektovani u medicinske svrhe. Intenzivna eksploatacija endoskopa počela je pronalaskom cistoskopa, na kome se zasnivao dalji razvoj savremene urologije. Posle toga razrađeni su bili uređaji nazvani boroskopi koji predstavljaju krut sistem sočiva snabdevenih minijaturnom lampom za osvetljavanje. Kod savremenih endoskopa lampa je zamenjena vlaknastim osvetljavajućim sistemom, koji dozvoljava veliko pojačanje intenziteta osvetljavanja, što omogućava snimanje predmeta posmatranja. Aktivno korišćenje elektronike, znatno je proširilo oblasti primene vizuelne kontrole i njenog video-snimanja.

\section{Boroskopi}

Kruti boroskopi poseduju jednostavan optički sistem sočiva koji je šematski prikazan na slici 1 [4]. Kod boroskopa je slika vrlo jasna, a pošto se ne koriste koherentni snopovi optičkih vlakana, oni su nekoliko puta jeftiniji od fiberskopa. Čvrstina konstrukcije, mogućnost izbora dužine, prečnika, ugla i polja vida, kao i jednostavnost upotrebe, čine boroskop rasprostranjenom opremom vizuelne kontrole. 


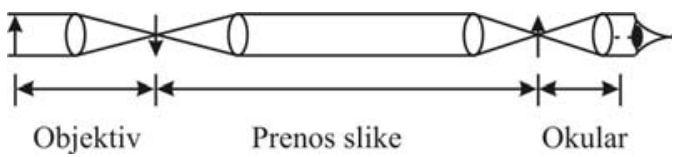

Sl. 1 - Šematski prikaz optičkog sistema boroskopa

Boroskopi promenljive dužine predviđeni su za kontrolu i pregled unutrašnjosti velikih šupljih konstrukcija, dugih cevi i drugih teško dostupnih delova. Boroskop se sastoji od cevi sa okularom (sa mogućnošću fokusiranja, električnim nastavkom i monokularnim adapterom) i od cevi objektiva, slika 2 [4]. Boroskopu pripadaju kablovi za priključenje na izvor svetlosti „svetlovod“, pribor za brisanje sočiva i kutija za skladištenje.

Gde god postoji mogućnost pristupa boroskopom, postoje velike mogućnosti za istraživanje, razvoj, kontrolu kvaliteta i održavanje različitih tehničkih sistema. Njegova primena moguća je na temperaturama do $150^{\circ} \mathrm{C} \mathrm{u}$ različitim sredinama (voda, ulje, slana voda, gorivo i sl.). Iako su pri tehničkoj dijagnostici često izloženi raznim vidovima nečistoća i agresivnim sredinama, boroskopi se lako održavaju, brisanjem posle upotrebe. Miniboroskop predstavlja specifičan tip boroskopa, čiji je prečnik samo $1,7 \mathrm{~mm}$, a koristi se za pregled kroz otvore malog prečnika.
Boroskopi se široko primenjuju za kontrolu cevi oruđa, parnih kotlova i hladnjaka, gasovoda, naftnih bušotina, plinskih boca, raznih vrsta cevi i sl.

\section{Fiberskopi}

Fiberskop je uređaj koji ima sposobnost savijanja svetlovoda bez posledica po sliku koju obrađuje, a sastoji od dva vlaknasta svetlovoda, objektiva i okulara. Šematski prikaz fiberskopa sa izvorom svetlosti prikazan je na slici 3 [4], a njegova konstrukcija na slici 4 [4].

$\mathrm{Za}$ fokusiranje fiberskopa pri različitim rastojanjima do objekta dijagnostike sočivo objektiva mora se pomerati u pravcu ose. Obično se njegov položaj reguliše distantno od okularnog dela fiberskopa. U okularu postoji specijalan dioptrijski prsten za prilagođavanje oku posmatrača (izoštravanje slike). Kvalitet slike je, u krajnjem, određen tačnošću rasporeda završetka vlakna na krajevima snopa za prenos slike. Kod fiberskopa firme OLYMPUS [5] praktično je postignut idealan raspored vlakana u sve tri dimenzije, za šta je, pre svega, neophodna stroga jednakost njihovih prečnika. Fiberskopi firme OLYMPUS imaju koherentnu sliku dobijenu kroz snop fiberop-

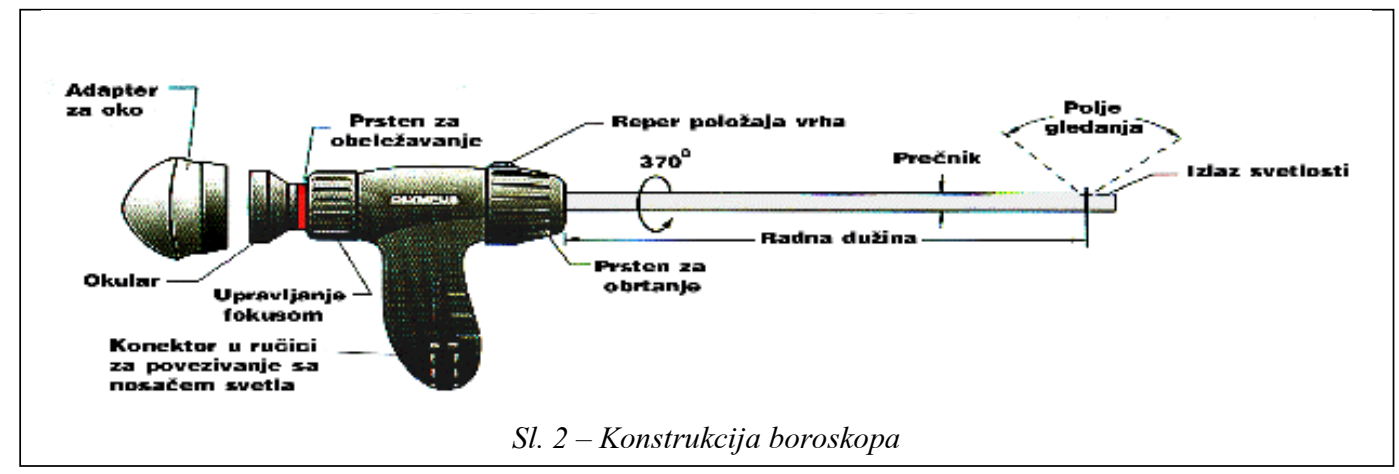



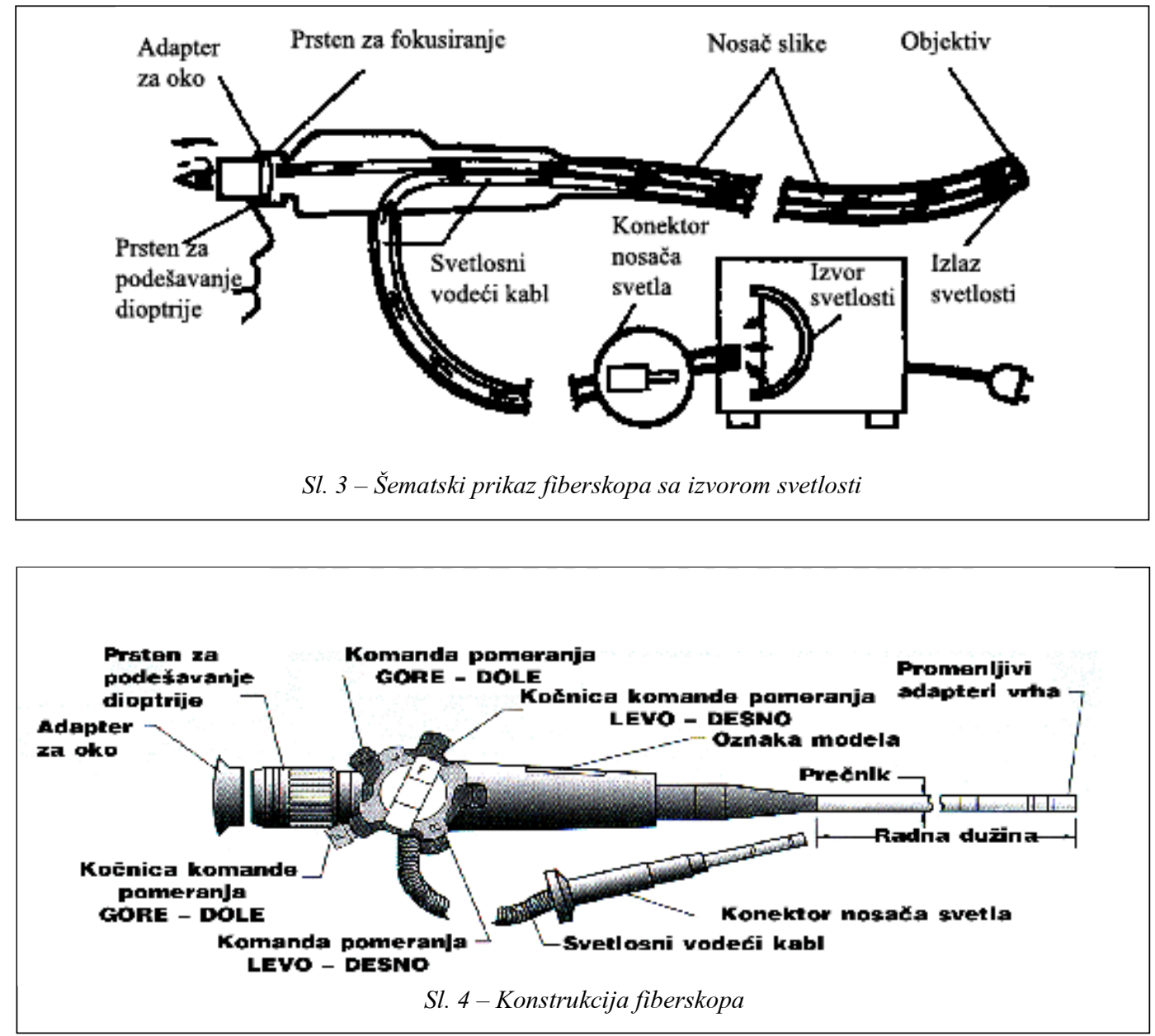

tičkih vlakana vrhunskog kvaliteta. Minimalni otvori kroz koje je moguće uvesti fiberskop je $2 \mathrm{~mm}$.

Fiberskop ima mogućnost savijanja svojih krajeva, što omogućava ne samo direktan, već i bočni pogled. Njegovi osnovni delovi su: koherentan snop vlakana za prenos slike, koji se prostire od glave koja se uvodi u prostor ispitivanja do ručice za upravljanje i okulara; svetlovod za osvetljavanje, tj. nekoherentni snop vlakana koji polazi od glave, vodi do ručice za upravljanje i dalje kroz spojnicu do svetlosnog izvora; tanke žice koje povezuju glavu sa ručicom za upravljanje i pričvršćuju se za regulator pravca glave koji omogućava operatoru da namesti glavu pod zadatim uglom (u dve ravni) i time obezbedi njen prolazak kroz složene kanale i pregled željenih zatvorenih prostora (kod fiberskopa OLYMPUS ugao otklona glave može biti $\pm 120^{\circ}$ ); četvoroslojna obloga koja obavija oba snopa optičkih vlakana i žičica, a elastična spoljna obloga obezbeđuje vodonepropusnost fiberskopa; ručica za upravljanje, koja obezbeđuje fokusiranje objektiva i okulara, željeno upravljanje krajevima fiberskopa i dobijanje željene slike. 
Pomoćni pribor koji se koristi u kombinovanju sa fiberskopom varira od video kamere, do različitih svetlosnih izvora i ugaonih adaptera za okular. Fiberskopu se, uz prethodni pribor, može omogućiti i spajanje sa TV ekranom, odnosno sa računarom i monitorom. To specijalistima omogućava razne pogodnosti u radu, i mogućnost dokumentovanja (memorisanja) nalaza, kasniju analizu podataka i obuku kadra. Ranije su korišćeni foto-aparati $35 \mathrm{~mm}$, koji su potisnuti razvojem računara i digitalnih kamera.

Fiberskopi se mogu upotrebljavati do temperature od $80^{\circ} \mathrm{C}$ i u različitim sredinama, ali se mora više voditi računa o mehaničkim oštećenjima zbog specifične konstrukcije.

\section{Videoendoskopi}

Videoendoskopi (slika 5) [4] predstavljaju najsavremeniji sistem daljinske kontrole ugrađen u savitljivu cev, kroz koju se istovremeno osvetljava i snima unutrašnjost. Savitljivi videoendoskop omogućava kontrolu kroz otvore prečnika većih od $4 \mathrm{~mm}$ i pristup unutrašnjem prostoru koji je ranije bio nedostupan za video kontrolu. Na njegovom vrhu nalazi se kamera - čip (CCD - Charge Coupled Device), tako da se dobija digitalna slika koja se može kompjuterski obrađivati, čuvati i distribuirati. Uočavanje stvarnih boja još jedna je važna mogućnost, a pokretni vrh sa kamerom omogućava kvalitetno pozicioniranje i dijagnostiku.

\section{Sistemi daljinskog vizuelnog pregleda}

Sistemi daljinskog vizuelnog pregleda (RVI - Remote Visual Inspection) najnoviji su oblici savremenih sistema endoskopske dijagnostike, koji pomažu u detekciji, posmatranju, analizi i memorisanju oštećenja nedostupnih normalnom ljudskom vidu. Sistem RVI sastoji se od: krutih boroskopa, savitljivih fiberskopa, videoendoskopa, koji su integrisani sa raznim drugim sistemima (najčešće računarskim) i omogućavaju najkompletniji uvid i analizu stanja tehničkih sistema.

Sistemi RVI predstavljaju već opisane varijante endoskopske opreme (boroskopi, fiberskopi i videoendoskopi), povezane sa računarom i video opremom, što omogućava daleko veću mogućnost obrade memorisanih slika pregledanih sklopova. Ovi sistemi eliminišu

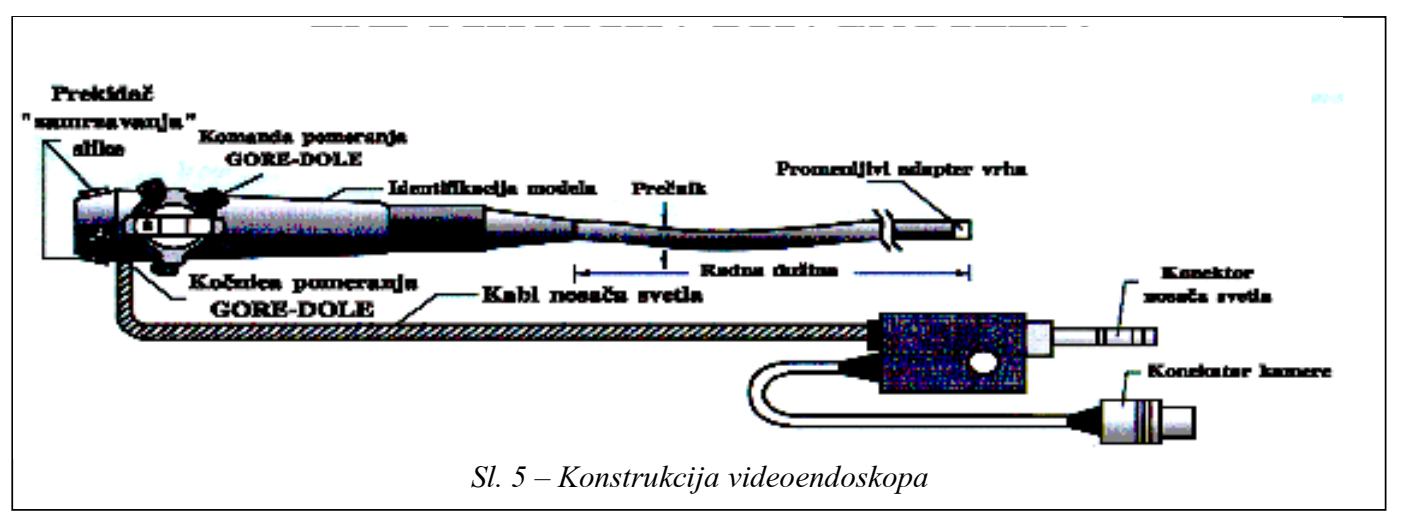




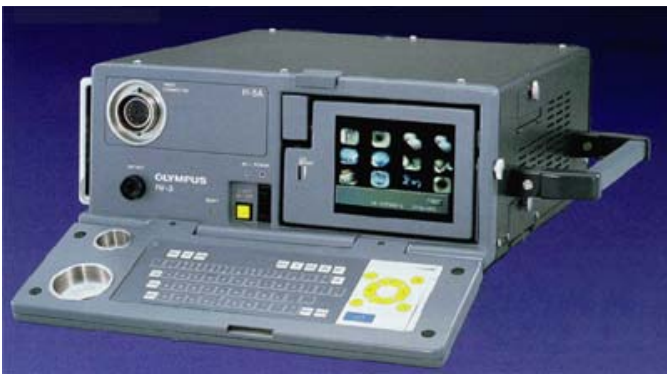

Sl. 6 - Videoanalizator $I W-2$

potrebu za rastavljanjem i nepotrebne duže prekide u eksploataciji, što dovodi do velikih ušteda, povećanja efektivnosti i pouzdanosti tehničkih sistema. Specifičnost savremenih sistema RVI ne ogleda se samo u uspešnoj dijagnostici unutrašnjih nepristupačnih oštećenja, već i u mogućnosti njihovog snimanja, memorisanja, obrade i naknadne analize.

Jasna i čista slika mesta koje se pregleda formira se u sistemu optike na vrhu endoskopa, sprovodi do posmatrača ili prikazuje uvećana i izoštrena na video ekranu ili monitoru visoke rezolucije.

Videoendoskopska oprema ima mogućnost, osim memorisanja slike snimanog dela, i merenje dimenzija oštećenja, kao i mogućnost formiranja i čuvanja svih podataka u datotekama (softverska podrška).

Video snimak može biti prikazan na standardnom monitoru, kompjuterizovanom video analizatoru (slika 6) ili video dokumentacionom sistemu (model VDS1). Videoanalizator (IW-2) [4] omogućava rad sa svim tipovima video endoskopa OLYMPUS, fiberskopa i boroskopa. Njegovom upotrebom moguće je beskontaktno merenje prečnika cevi ili dužine nekog oštećenja (prskotine). Najnovija kompjuterska tehnologija omogućava savršenu obradu digitalne slike, a postoji i mogućnost merenja dimenzija sa digitalne slike i štampanje dobijenih slika.

Najpoznatiji proizvođač endoskopske opreme u svetu je firma Olympus Industrial čiji je program prisutan i u našoj zemlji. Kompleti njihove opreme koncipirani su sa velikom univerzalnošću, što ih čini vrlo praktičnim u raznovrsnoj primeni.

\section{Endoskopska oprema novije generacije}

Novija generacija endoskopske opreme predstavlja značajan napredak $\mathrm{u}$ razvoju opreme za endoskopsku dijagnostiku. U jednu mobilnu celinu integrisani su videoanalizator i videoendoskop. Unapređen je softver za upravljanje, merenje dimenzija, obradu i arhiviranje, a postoji i mogućnost modemskog slanja memorisanih slika.

Na slici 7 prikazana je endoskopska oprema novije generacije, koju je, takode, proizvela firma Olympus Industrial [5], a nosi naziv IPLEX. Oprema je kompaktna i spakovana u kutiju otpornu na udarce. U kutiji je smešten doboš za namotavanje savitljivog videoendoskopa, kao i motor za upravljanje njegovim vrhom. Komande za njegovo upravljanje daju se preko višefunkcionalnog daljinskog upravljača.

Videoendoskop može biti prečnika $6 \mathrm{~mm}$ ili $4,4 \mathrm{~mm}$ i dužine od $3,5 \mathrm{~m}$ do $9,6 \mathrm{~m}$ za prečnik $6 \mathrm{~mm}$ i $3,5 \mathrm{~m}$ za prečnik 4,4 mm. Izvor svetla je halogena sijalica od $50 \mathrm{~W}$. Za prikazivanje rezultata endoskopske dijagnostike služi LCD monitor 5,6" visoke rezolucije, a ostali spoljašnji priključci su: USB konektor, priključak za memorijske kartice, video izlaz i S-video ulaz/izlaz. 


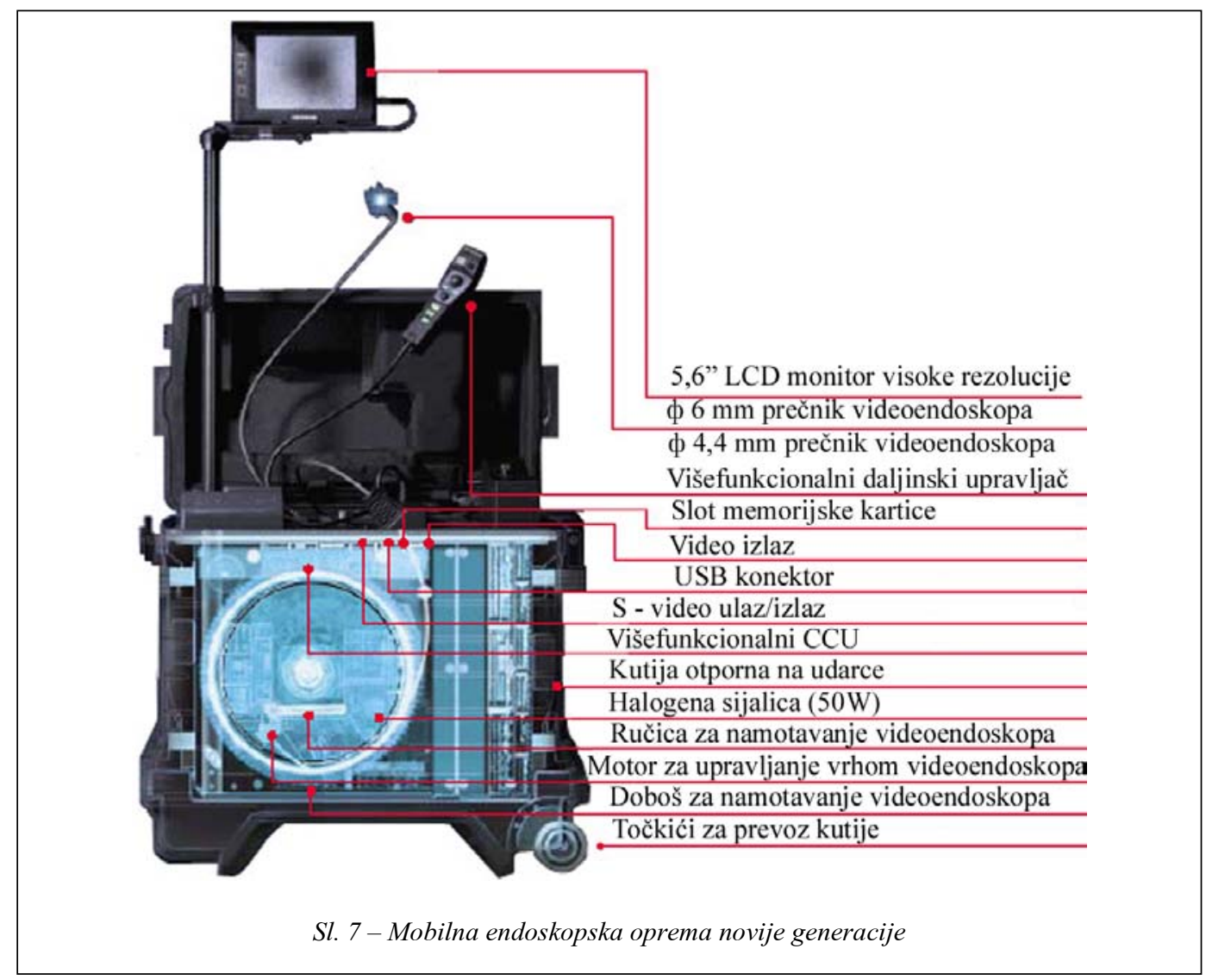

Endoskopska oprema prati razvoj elektronike i koristi najnovija tehnološka dostignuća. Iskorišćene su i mogućnosti koje pruža savremena informatička tehnologija, a to je da se rezultati endoskopske dijagnostike mogu odmah memorisati u računaru gde će se izvršiti njihova obrada uz pomoć najnovijeg softvera. Rezultati se mogu proslediti, putem modemske veze, do nekog drugog odredišta, tj. kompjutera.

Unapređenje softvera ogleda se u tome što se sada pomoću njega mogu izmeriti dubine, dužine, površine i reljefi oštećenja. Ove mogućnosti prikazane su na slici 8 [5].

\section{Metodologija primene endoskopske dijagnostike}

Za uvođenje endoskopske dijagnostike u proces održavanja tehničkih sistema potrebno je definisati metodologiju po kojoj bi se sproveo program endoskopske kontrole. Metodologiju endoskopske dijagnostike definišu sledeće faze:

1. analiza konstruktivnog rešenja objekta dijagnostike;

2. određivanje kontrolnih mesta i izbor pristupnih otvora za uvođenje endoskopa;

3. izbor endoskopske opreme;

4. definisanje postupka i analiza rezultata endoskopske dijagnostike;

5. izrada izveštaja. 
Prvi korak za primenu endoskopske dijagnostike predstavlja detaljno upoznavanje sa konstrukcijom i sistemom održavanja objekta dijagnostike. Zbog toga je neophodno upoznavanje sa delovima i sklopovima koji se pregledaju, u pogledu: opterećenja, mesta kritičnih naprezanja, tehnologije izrade, sistema povezivanja elemenata, materijala, površinske zaštite, moguće vrste oštećenja, postojećeg sistema održavanja...

Definisanje kontrolnih mesta sledeća je faza metodologije endoskopske dijagnostike, u kojoj se određuju mesta koja treba pregledati. Kontrolna mesta definišu se posle upoznavanja sa tehničkim sistemom i njegovim održavanjem.

Kontrolna mesta određuju se tako da pregledom budu obuhvaćeni svi vitalni delovi i sklopovi tehničkog sistema. $\mathrm{Na}$ osnovu sagledavanja procesa koji se odvijaju u tehničkom sistemu, mogućih vrsta oštećenja i ostalih bitnih faktora koji utiču na rad sistema, vrši se određivanje kontrolnih mesta. Njihov broj zavisi od složenosti tehničkog sistema.

Posle određivanja kontrolnih mesta sledi analiza mogućnosti iskorišćenja postojećih otvora na tehničkom sistemu za uvođenje endoskopa u unutrašnjost tehničkog sistema radi pregleda definisanih kontrolnih mesta. U slučaju potrebe mogu se izraditi i novi tehnološki otvori za uvođenje endoskopske opreme, vodeći računa da ne ugrožavaju konstrukciju i ne ometaju rad tehničkog sistema.

Za efikasno sprovođenje endoskopske dijagnostike, endoskopska oprema uvek se bira prema odabranim otvorima kroz koje će se endoskopi uvoditi, kao i prema dužini uvođenja endoskopa sa pratećim adapterima (bočni ili direktni po-

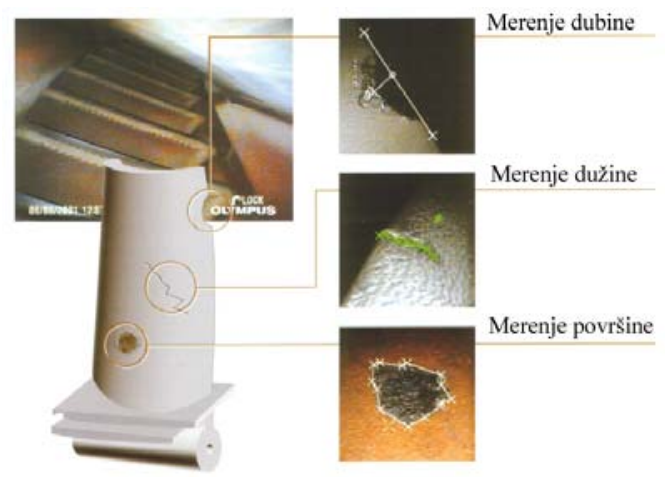

Slika 8-Merenje dubine, dužine i površine oštećenja

gled, širina pogleda i fokusa). Pravilan izbor izvora svetlosti, kao i ostale dopunske opreme, takođe utiče na kvalitet rezultata dijagnostike.

Novija generacija endoskopske opreme predstavlja jednu mobilnu celinu u koju su integrisani video analizator i video endoskop zajedno sa izvorom svetlosti. Na LCD monitoru visoke rezolucije prikazuju se rezultati endoskopske dijagnostike. Pri upotrebi ove opreme potrebno je samo izvršiti izbor adaptera za određivanje fokusa, pravca i širine pogleda. Jedna od najvažnijih faza endoskopske dijagnostike obuhvata analizu dobijenih rezultata. U toku endoskopske dijagnostike u poseban obrazac unose se zapažanja o nađenom stanju tehničkog sistema, sa oznakama memorisanih slika. Time je, u stvari, definisan postupak endoskopske dijagnostike konkretnog tehničkog sistema.

Rezultati endoskopske dijagnostike su slike otkrivenih oštećenja ili nekih karakterističnih delova sistema. One se memorišu u videoanalizatoru, a kasnije se mogu prebaciti u računar i arhivirati. Analiza rezultata podrazumeva upoređivanje konstatovanih oštećenja sa kriteri- 
jumima dozvoljenih oštećenja, radi donošenja odluke o nastavku eksploatacije objekta dijagnostike. Procena kriterijuma prihvatljivosti oštećenja na delovima tehničkih sistema predstavlja cilj celokupnog pregleda, jer daje odgovor na pitanje u kakvom se stanju nalazi ispitivani tehnički sistem. Na osnovu procene kriterijuma prihvatljivosti oštećenja donosi se odluka o daljem tehničkom saniranju oštećenja ili nastavku eksploatacije.

Za praćenje i usvajanje kriterijuma prihvatljivosti oštećenja delova tehničkih sistema neophodno je rezultate i podatke do kojih se dolazi pri povremenim endoskopskim pregledima beležiti u određena dokumenta (liste pregleda). Kriterijumi prihvatljivosti nađenih oštećenja definišu se posebnim dokumentima sa pratećim skicama, slikama i crtežima. Ti dokumenti najčešće su tabele koje sadrže: mesto pregleda, vrstu oštećenja, maksimalno dozvoljene dimenzije i količine dozvoljenih oštećenja.

Procena kriterijuma prihvatljivosti oštećenja delova tehničkih sistema vrši se upoređenjem oštećenja sa etalonima. Ovaj kriterijum predviđa postojanje etalona koji su rezultat dugotrajnog praćenja i izučavanja razvoja oštećenja i usvajanja granica dozvoljenih oštećenja sa kojima tehnički sistem i dalje zadržava zadovoljavajuću radnu sposobnost.

Etalon može biti posebno pripremljeni deo, crtež, skica, fotografija, memorisana slika sa što preciznije definisanim kriterijumima oštećenja (dužina, dubina, površina, mesto, broj, oblik, itd.). Takođe, kao etalon mogu poslužiti i vrednosti proračunate na osnovu čvrstoće ili dobijene eksperimentalnim ispitivanjem na zamor.

Poznavajući konstrukciju tehničkih sistema, tj. delove i sklopove sistema koji se dijagnosticiraju, njihove tehničko-tehnološke karakteristike i uslove u kojima rade, mogu se predložiti vremenski intervali sledećih pregleda. Oni bi omogućili praćenje oštećenja na delovima tehničkih sistema, na osnovu kojih bi se kasnije mogli usvojiti nepostojeći kriterijumi prihvatljivosti oštećenja. Ti kriterijumi kasnije bi pomogli u usvajanju i izradi etalonskih delova, koji bi služili za analizu u procesu definisanja kriterijuma prihvatljivosti oštećenja delova tehničkih sistema.

Poslednja faza definisane metodologije primene endoskopske dijagnostike je donošenje zaključka, ocene stanja njegovih sklopova (delova) i sistema u celini kroz izradu izveštaja.

$\mathrm{Na}$ osnovu dobijenih rezultata u Izveštaju endoskopske dijagnostike daje se jasan zaključak sa predlogom mera o daljoj eksploataciji objekta dijagnostike, odnosno o postupcima održavanja koje je potrebno preduzeti odmah ili kasnije u fazama.

Prilog Izveštaja obavezno sadrži sve slike registrovanih oštećenja koja će se pratiti u sistemu održavanja prema stanju tehničkog sistema. Izveštaj daje precizan odgovor o uzroku nastanka otkaza, sa predlogom mera kako da se spreči pojava sličnog otkaza na ostalim tehničkim sistemima. Takođe, moraju se preporučiti intervali budućih pregleda, koji će, uglavnom, zavisiti od nađenog stanja i eksploatacije tehničkog sistema. 


\section{Zaključak}

Upotrebom odgovarajuće endoskopske opreme moguće je u zatvorenom, neosvetljenom i skučenom prostoru pouzdano otkrivanje oštećenja, kao što su: prskotine, zarezi, deformacije, korozija, erozija, istrošenja, izgoretine, gubitak zaštitnih prevlaka, naslage, curenja i dr.

Endoskopska dijagnostika ima mogućnosti za veoma široku primenu, i skoro da nema oblasti gde se ne bi mogla koristiti. Može se upotrebiti za utvrđivanje trenutnog stanja raznih tehničkih sistema, kao što su: transportna i građevinska sredstva, nuklearni reaktori, parni kotlovi sa instalacijama i dr., kao i njihovih podsistema (elementi konstrukcije, pogonske grupe, prenosnici snage, sudovi pod pritiskom, turbomašine, izmenjivači toplote...).

Endoskopska dijagnostika se uspešno primenjuje u održavanju raznih teh- ničkih sistema. Na osnovu dobijenih podataka moguće je izvršiti detaljnu analizu svih vidljivih oštećenja, upotrebom odgovarajuće računarske opreme i softvera, pri čemu se može predložiti način upotrebe uređaja ili sistema za određeni period.

Cilj primene endoskopske dijagnostike jeste uvođenje održavanja prema stanju $\mathrm{u}$ sistemu, uz povećanje pouzdanosti i efektivnosti složenih tehničkih sistema.

\section{Literatura:}

[1] Petrović, Ž.: Primena metode endoskopske dijagnostike u održavanju tehničkih sistema, magistarski rad, Mašinski fakultet, Beograd, 2004.

[2] Janković, S.; Jovanović, M.: Mogućnosti primene savremene endoskopske dijagnostike u održavanju prema stanju u naftnoj industriji Jugoslavije, YUNG 2002.

[3] Janković, S.; Jovanović, M.: Održavanje prema stanju vazduhoplovnih gasoturbinskih motora primenom endoskopske dijagnostike, 6 QDM konferencija, 18-19.06.2003.

[4] Časopisi i prospektni materijal za endoskopsku dijagnosti$\mathrm{ku}$, Olympus Industrial.

[5] www.olympus-industrial.co.uk 